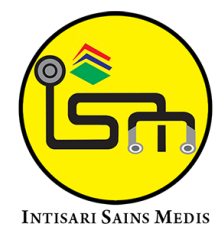

Published by Intisari Sains Medis

\title{
Karakteristik gambaran Tuberkulosis (TB) paru pada foto toraks pasien Human Immunodeficiency Virus (HIV) tahun 2017-2021 di RSUP Sanglah, Bali, Indonesia
}

\author{
Tiffany Rebecca ${ }^{1 *}$, Dewa Gde Mahiswara Suadiatmika ${ }^{2}$, Ni Nyoman Margiani ${ }^{2}$
}

${ }^{1}$ Mahasiswa Program Studi Pendidikan Dokter, Fakultas Kedokteran, Universitas Udayana, Bali, Indonesia

2Departemen Radiologi, Fakultas Kedokteran, Universitas Udayana, RSUP Sanglah, Bali, Indonesia

*Korespondensi:

Tiffany Rebecca; Mahasiswa Program Studi

Pendidikan Dokter, Fakultas Kedokteran, Universitas Udayana, Bali, Indonesia;

rebeccatiffany18@gmail.com

\section{ABSTRACT}

Background: Tuberculosis is a disease caused by Mycobacterium tuberculosis that mostly attacks the lungs. HIV is a virus that causes damage to the immune system. HIV infection increases the risk of developing pulmonary TB because TB is an opportunistic disease; vice versa TB infection increases HIV progression. This study is about researching the characteristics of TB in HIV patients radiologically at Sanglah Hospital Denpasar.

Methods: This study is a cross-sectional descriptive study conducted retrospectively. The data in this study used medical records of HIV-infected pulmonary TB patients from Sanglah Hospital, especially the characteristics of chest radiographs in the medical records and chest $X$-rays of patients. For the data collecting technique, a total sample is used to analyze all 47 cases. Data were analyzed using SPSS version 25 for Windows.

Results: Most HIV patients with pulmonary TB coinfection at Sanglah Hospital, Denpasar, were obtained from as many as 47 people. It was found that the age between 30 - 39 recorded to be the highest at $31.3 \%$, men were the most dominant with $81.3 \%$, most of the patients diagnosed with HIV stage 4 were $72.9 \%$, and the most dominant characteristics of the chest radiograph are $41.7 \%$ consolidation.

Conclusion: Most cases of pulmonary TB with HIV coinfection at Sanglah Hospital Denpasar in 2017 2021 are male around 30 - 39 years. In addition, most of them were diagnosed with HIV stage 4 and finally almost all the patients had consolidation characteristics on chest radiographs.

\section{Keywords: Characteristics, HIV/AIDS, Tuberculosis Coinfection, Sanglah General Hospital}

Cite This Article: Rebecca, T., Suadiatmika, D.G.M., Margiani, N.N. 2021. Karakteristik gambaran Tuberkulosis (TB) paru pada foto toraks pasien Human Immunodeficiency Virus (HIV) tahun 2017-2021 di RSUP Sanglah, Bali, Indonesia. Intisari Sains Medis 12(3): 934-938. D01: 10.15562/ism.v12i3.1194

\section{ABSTRAK}

Latar Belakang: Tuberkulosis adalah penyakit yang disebabkan oleh Mycobacterium tuberculosis yang paling banyak menyerang paru-paru. HIV adalah virus yang menyebabkan kerusakan pada sistem kekebalan tubuh. Infeksi HIV meningkatkan risiko berkembangnya TB paru karena TB adalah penyakit oportunistik sebaliknya infeksi TB meningkatkan perkembangan HIV. Penelitian ini bertujuan untuk mengetahui karakteristik TB pada pasien HIV secara radiologis di RSUP Sanglah Denpasar.

Metode: Penelitian ini merupakan penelitian deskriptif potong lintang yang dilakukan secara retrospektif. Data dalam penelitian ini menggunakan rekam medis pasien TB paru terinfeksi HIV dari RSUP Sanglah, terutama karakteristik foto toraks pada rekam medis dan foto rontgen dada pasien. Untuk teknik pengumpulan data, sampel total digunakan untuk menganalisis semua 47 kasus. Data dianalisis dengan SPSS versi 25 untuk Windows.

Hasil: Pasien HIV koinfeksi TB paru terbanyak di RS Sanglah Denpasar didapatkan sebanyak 47 orang. Didapatkan usia antara 30-39 tahun tercatat paling tinggi $31,3 \%$, laki-laki paling dominan dengan $81,3 \%$, sebagian besar pasien terdiagnosis HIV stadium 4 sebanyak $72,9 \%$, dan karakteristik foto toraks yang paling dominan adalah konsolidasi $41,7 \%$. 
Kesimpulan: Kasus TB paru koinfeksi HIV terbanyak di RSUP Sanglah Denpasar tahun 2017 - 2021 adalah laki-laki berusia sekitar 30-39 tahun. Selain itu, sebagian besar terdiagnosis HIV stadium 4 serta hampir semua pasien memiliki karakteristik konsolidasi pada radiografi dada.

Kata Kunci: HIV/AIDS, Karakteristik, Koinfeksi TB, RSUP Sanglah

Sitasi Artikel ini: Rebecca, T., Suadiatmika, D.G.M., Margiani, N.N. 2021. Karakteristik gambaran Tuberkulosis (TB) paru pada foto toraks pasien Human Immunodeficiency Virus (HIV) tahun 2017-2021 di RSUP Sanglah, Bali, Indonesia. Intisari Sains Medis 12(3): 934-938. D0I: 10.15562/ism.v12i3.1194

\section{PENDAHULUAN}

Tuberkulosis (TB) paru telah menjadi salah satu masalah kesehatan terbesar di dunia maupun di Indonesia. TB merupakan salah satu dari 10 penyebab kematian dan agen infeksius. ${ }^{1}$ Penyakit TB disebabkan oleh bakteri Mycobacterium tuberculosis dan sering menyerang paru-paru tetapi juga dapat menyerang anggota tubuh lainnya. TB dapat menular dan menyebar dari satu orang ke orang lainnya melalui udara. ${ }^{2}$ Menurut WHO, Estimasi kasus TB seluruhnya sebesar 660,000 dan estimasi insidensi berjumlah 430,000 kasus baru per tahun serta jumlah kematian akibat TB sekitar 61,000 kematian per tahunnya. ${ }^{2,3}$ Angka ini diprediksi terus meningkat seiring dengan semakin tingginya kejadian TB dengan koinfeksi virus Human Immunodeficiency Virus (HIV).

HIV adalah virus yang menyerang sistem kekebalan tubuh, khususnya sel CD4 atau disebut juga sel $\mathrm{T}$ dimana dapat jatuh dalam keadaan Acquired Immunodeficiency Syndrome (AIDS). ${ }^{4}$ HIV adalah virus sitopatik yang berasal dari famili retrovirus, dapat menggunakan RNA dan DNA inang untuk membentuk virus DNA, merusak sistem kekebalan tubuh. ${ }^{5}$ Masalah HIV/AIDS merupakan masalah besar yang mengancam Indonesia dan banyak negara di dunia. Hingga saat ini, HIV/AIDS telah menyebar ke 386 kabupaten/kota di seluruh provinsi di Indonesia. Jumlah kumulatif penderita HIV dari tahun 1987 sampai September 2014 adalah 150.296. Pada tahun 2016, jumlah infeksi HIV di Indonesia diperkirakan $620.000 .{ }^{6}$

Dampak pandemi HIV di dunia akan menambah permasalahan TB. Menurut WHO 2016, diperkirakan ada 10,4 juta kasus baru tuberkulosis di seluruh dunia. ${ }^{1,2}$ Enam negara dengan jumlah kasus tuberkulosis tertinggi pada tahun 2015 adalah India, Indonesia, China, Nigeria, Pakistan dan Afrika Selatan. Pada tahun 2015, sekitar 1,8 juta orang meninggal karena TB, termasuk 400.000 orang yang hidup dengan HIV. TB merupakan salah satu dari 10 penyebab kematian di dunia setelah HIV dan malaria. Diperkirakan 1,2 juta dari 10,4 juta pasien TB di seluruh dunia adalah HIV-positif dan sekitar 35\% telah meninggal. ${ }^{1,2}$

Pada tahun 2013, Indonesia menjadi salah satu negara dengan prevalensi TB tertinggi setelah Cina, India, Nigeria dan Pakistan terutama di daerah Jawa-Barat. TB dan HIV merupakan dua penyakit yang saling berkaitan dan semakin meningkat jumlah kasusnya. ${ }^{7}$ Di tahun 2017, TB menyebabkan 1,2-1,4 juta kematian pada orang-orang dengan HIV negatif tapi juga menyebabkan sekitar 266.000-335.000 kematian di antara orang dengan HIV positif. Diperkirakan terdapat 9-11 juta kasus TB baru setara dengan 133 kasus per 100.000 penduduk. Di tahun 2017, terdapat sekitar 558.000 kasus TB baru secara global. Jumlah kematian yang disebabkan TB di antara HIV negatif mengalami penurunan menjadi $29 \%$ sejak tahun 2007 dan diprediksi pada tahun 2015 angka kematian menjadi $5 \%{ }^{8}$

Koinfeksi HIV dengan tuberkulosis merupakan masalah yang serius, jika tidak dikelola dengan baik maka tidak akan dapat dikendalikan, sehingga menjadi ancaman bagi kesehatan masyarakat secara global. Untuk mengatasi masalah ini, perlu dipahami karakteristik pasien TB paru koinfeksi HIV, karena manifestasi klinis yang tidak khas, yang akan menyebabkan keterlambatan diagnosis dan pengobatan, dan pada akhirnya menyebabkan peningkatan kematian. Oleh karena itu, perlu dipahami karakteristik klinis, hasil laboratorium dan radiologis pasien tuberkulosis paru koinfeksi HIV. Berdasarkan pemaparan di atas, penelitian ini bertujuan untuk mengetahui usia, jenis kelamin, stadium HIV, dan karakteristik TB yang terdapat pada foto toraks pasien HIV di RSUP Sanglah Denpasar, Bali periode 2017 - 2021.

\section{METODE}

Penelitian ini adalah penelitian deskriptif potong lintang yang dilakukan secara retrospektif terhadap 47 data rekam medis pasien TB dan HIV yang dikumpulkan dari Departemen Radiologi, RSUP Sanglah, Bali, Indonesia selama periode Januari-Juli 2021 menggunakan teknik Total Sampling. Data dikumpulkan dengan melihat rekam medis pasien-pasien TB dan HIV terutama pada bagian radiologi yaitu gejala pada foto toraks. Data terkait faktor risiko pasien terkena TB dan HIV serta karakteristik radiologi yang terlihat pada foto toraks terlibat pada penelitian ini. Deskripsi karakteristik sampel dilakukan dengan menyajikan data dalam bentuk frekuensi

Adapun kriteria inklusi dalam penelitian ini meliputi semua pasien rawat inap yang terkena TB dan HIV di RS Sanglah, memiliki batas umur di atas 17 tahun, memiliki rekam medis dan foto toraks periode 2017-2021, serta foto toraks yang dibutuhkan diambil sebelum pasien TB-HIV menerima pengobatan. Adapun kriteria eksklusi untuk penelitian ini adalah foto toraks pasien yang kurang jelas untuk dievaluasi serta data pasien hilang. 
Variabel penelitian yang diukur pada penelitian ini meliputi usia, jenis kelamin, stadium klinis HIV, dan karakteristik radiologis TB pada pasien HIV (konsolidasi, kavitas, infiltrat, fibroinfiltrat, fibrosis, kalsifikasi, atelektasis paru, efusi pleura, dan milier). Analisis deskriptif yang dilakukan meliputi analisis frekuensi. Penyajian data variabel karakteristik yang bersifat kategorikal dalam bentuk distribusi frekuensi serta persentase. Analisa data dilakukan dengan menggunakan perangkat lunak Statistical Product and Service Solutions (SPSS) versi 25 untuk Windows.

\section{HASIL}

Hasil penelitian ini menunjukkan bahwa sebagian besar responden dengan TB dan HIV berdasarkan umur terdapat pada pasien yang berumur sekitar penelitian berusia 30-39 tahun (29,8\%), diikuti dengan usia 40-49 tahun (27,7\%), 20-29 tahun (23,4\%), 50-59 tahun (12,8\%), dan 60-69 tahun (6,4\%) (Tabel 1). Sebagian besar responden diketahui berjenis kelamin laki-laki (83,0\%). Pasien HIV dengan koinfeksi TB sebagian besar terdiagnosis dengan kondisi klinis HIV yang buruk yaitu HIV stadium 4 (72,3\%) menurut klasifikasi WHO diikuti dengan stadium $3(19,1 \%)$, stadium 1 (4,3\%), dan stadium 2 (4,3\%) (Tabel 1).

Berdasarkan karakteristik foto toraks, hasil penelitian ini menunjukkan bahwa yang paling banyak ditemukan pada pasien TB dan HIV adalah jenis konsolidasi sebanyak $42,6 \%$ dan fibroinfiltrat $(40,4 \%)$. Kemudian, data tersebut diikuti dengan kavitas $(36,2 \%)$ dan berikutnya dengan milier yaitu 23,4\%. Sedangkan, karakteristik yang paling sedikit ditemukan pada data rekam medis pasien adalah efusi pleura, kalsifikasi, fibrosis dan atelektasis paru dengan persentase masing - masing 2,1\% (Tabel 2).

\section{PEMBAHASAN}

Tuberkulosis (TB) merupakan penyakit menular yang disebabkan oleh bakteri Mycobacterium tuberculosis dan sering menyerang paru-paru tetapi juga dapat menyerang anggota tubuh lainnya. TB dapat menular dan menyebar dari satu orang ke orang lainnya melalui udara. ${ }^{9}$

Tabel 1. Distribusi Pasien HIV koinfeksi TB di RSUP Sanglah Denpasar tahun $2017-2021$

\begin{tabular}{ccc}
\hline Variabel & Jumlah $(\mathbf{N}=\mathbf{4 7})$ & Persentase $(\%)$ \\
\hline Usia (Tahun) & 11 & 23,4 \\
$20-29$ & 14 & 29,8 \\
$30-39$ & 13 & 27,7 \\
$40-49$ & 6 & 12,8 \\
$50-59$ & 3 & 6,4 \\
$60-69$ & & \\
Laki-Laki & 39 & 83,0 \\
Perempuan & 8 & 17,0 \\
Stadium Klinis HIV & & 4,3 \\
2 & 2 & 4,3 \\
3 & 2 & 19,1 \\
4 & 9 & 72,3 \\
\hline
\end{tabular}

HIV: Human Immunodeficiency Virus

Tabel 2. Evaluasi karakteristik foto toraks pasien HIV koinfeksi TB di RSUP Sanglah Denpasar tahun 2017 - 2021

\begin{tabular}{cccc}
\hline & \multicolumn{2}{c}{ Frekuensi } & \\
\cline { 2 - 3 } Karakteristik & $\mathbf{N}$ & $\%$ & Persentase (\%) \\
\hline Konsolidasi & 20 & 26,0 & 42,6 \\
Milier & 11 & 14,3 & 23,4 \\
Kavitas & 17 & 22,1 & 36,2 \\
Fibroinfiltrat & 19 & 24,7 & 40,4 \\
Infiltrat & 4 & 5,1 & 8,5 \\
Efusi Pleura & 2 & 2,6 & 4,3 \\
Atelektasis Paru & 2 & 2,6 & 4,3 \\
Kalsifikasi & 1 & 1,3 & 2,1 \\
Fibrosis & 1 & 1,3 & 2,1 \\
\hline
\end{tabular}

TB merupakan penyebab kematian ketiga tertinggi akibat infeksi di dunia. Berdasarkan perkiraan Organisasi Kesehatan Dunia (WHO), TB telah tercatat dalam menginfeksi sekitar sepertiga populasi dunia disertai dengan 1,5 juta kasus kematian setiap tahun. ${ }^{10}$ Pada tahun 2016, sekitar 10,4 juta orang menderita TB dan sekitar 1,7 orang meninggal karena penyakit TB (termasuk 0,4 juta orang di antaranya merupakan penderita HIV). Lebih dari 95\% kematian yang disebabkan TB terjadi di negaranegara dengan penghasilan menengah ke bawah. India, Indonesia, Cina, Filipina,
Pakistan, Nigeria, dan Afrika Selatan merupakan 7 negara dengan tingkat insidensi tertinggi. ${ }^{11}$

HIV/AIDS adalah suatu penyakit global yang sudah lama dikenal. Infeksi ini disebabkan oleh human immunodeficiency virus (HIV) yang nantinya akan menyebabkan turunnya sistem imunitas tubuh dan membuat tubuh semakin rentan terhadap penyakit oportunistik lainnya. Penyakit tuberkulosis dan HIV adalah dua penyakit infeksi yang angka prevalensinya terus meningkat. ${ }^{12}$ Kedua penyakit ini memiliki korelasi yang erat karena HIV membuat pasien menjadi 
lebih rentan terhadap TB kemudian TB memperburuk prognosis pasien HIV ${ }^{13}$ Resiko penularan dan perkembangan TB aktif pada individu normal diperkirakan sekitar 5-10\%, sedangkan pada individu dengan HIV positif risiko meningkat menjadi $5-15 \% .{ }^{13}$

Pada penelitian ini, penulis akan berfokus untuk membahas mengenai karakteristik tuberkulosis pada pasien HIV di RSUP Sanglah Denpasar tahun 2017-2021 yang mencakup usia, jenis kelamin, stadium HIV klinis, dan karakteristik foto toraks pasien. Data yang diambil dari rekam medis pasien dan foto thoraks pasien pada departemen radiologi di RSUP Sanglah Denpasar pada tahun 2017-2021 menunjukkan sebagian besar pasien TB dan HIV berusia antara 30 sampai 39 tahun, dengan jumlah kasus sebanyak 14 kasus. Dan puncak kedua adalah rentang umur 40 - 49 tahun sekitar 13 kasus.

Data tersebut konsisten dengan data pada penelitian Yusuf NF di Rumah Sakit Umum Pusat Wahidin Sudirohusodo Makassar yang menyatakan seseorang suspek terkena koinfeksi TB-HIV adalah antara 30 - 40 tahun. ${ }^{14}$ Penelitian sebelumnya menunjukkan terdapat 33 orang pasien $(47,1 \%)$ dengan rentang waktu 30-40 tahun. Hasil ini juga ditegakkan dengan penelitian sebelumnya tahun 2016 di RSUD Dr. Saiful Anwar Malang yang memperlihatkan bahwa umur antara 30 sampai 34 tahun lebih banyak terkena TB dan HIV. ${ }^{15}$ Begitu juga penelitian di RSUP Haji Adam Malik memperlihatkan bahwa pasien di bawah 49 tahun lebih banyak terkena TB dan HIV daripada pasien di atas 50 tahun. ${ }^{11}$ Sedangkan penelitian Krisnahari KL et al., pada tahun 2018 dan penelitian Soraya DAH et al., di RSUP Sanglah Denpasar tahun 2016 memperlihatkan rentang 15-35 tahun lebih banyak menerima kasus TB dan HIV daripada orang yang berumur $>35$ tahun. ${ }^{12,13}$ Begitu juga penelitian di Rumah Sakit Penyakit Infeksi (RSPI) Prof. Dr. Sulianti Saroso oleh Rosamarlina NFN et al., tahun 2017 memperlihat kasus TB dan HIV terdapat pada pasien berumur kurang dari 35 tahun. ${ }^{16} \mathrm{Hal}$ ini bisa dinyatakan variabel umur pada setiap penelitian TB dan HIV bervariasi berdasarkan lokasi dan waktu pengambilan data. Dan berdasarkan pembahasan ini, bisa dikatakan resiko orang terkena TB dan HIV adalah antara 20 - 50 tahun. Peningkatan kasus TB dan HIV disebabkan karena orang pada kelompok usia ini merupakan orang yang berada dalam usia produktif secara ekonomis. Pada usia ini, pasien mengalami peningkatan aktifitas seperti interaksi dan mobilitas sosial serta aktivitas seksual yang tinggi pada usia produktif, pengaruh lingkungan, dan pekerjaan sehingga meningkatkan penularan TB dan HIV di masyarakat. ${ }^{7,14}$

Seperti yang kita lihat pada hasil penelitian demografi, kasus TB dan HIV didominasi oleh laki - laki daripada perempuan yaitu sebanyak 39 orang. Beberapa penelitian juga menunjukkan hasil yang sama pada kasus pasien HIV koinfeksi TB. Penelitian oleh Yusuf NF menunjukan kasus terbanyak TB dan HIV adalah berjenis kelamin laki-laki (74,3\%), sedangkan penelitian di RSUP Haji Adam Malik oleh studi sebelumnya menunjukkan jenis kelamin laki-laki kasus TB dan HIV sekitar $77,5 \% .{ }^{11,14}$ Hal yang sama terdapat pada hasil penelitian di RSUD Badung dan Klinik Bali Medika Kuta, serta beberapa studi lainnya yang menunjukkan jenis kelamin laki-laki adalah dominan. ${ }^{11-13}$ Resiko lebih tinggi untuk TB dan HIV pada laki-laki dikarenakan lebih banyak melakukan aktivitas di luar rumah dan juga pengaruh dari lingkungan pergaulan sehingga kemungkinan untuk lebih mudah terpapar. ${ }^{11}$

Untuk penelitian ini, Stadium HIV yang dimiliki pasien dikelompokkan menurut WHO. Berdasarkan WHO, HIV dibagi menjadi stadium 1 (asimtomatik), stadium 2 (ringan), stadium 3 (sedang) dan stadium 4 (berat). Sebagian besar terdiagnosis dengan kondisi klinis HIV yang buruk yaitu HIV stadium 4 yaitu 34 kasus diikuti dengan stadium 3. Sedangkan stadium 1 dan 2, hanya 2 orang dari 47 pasien terdiagnosis stadium tersebut baik stadium 1 maupun stadium 2. Hasil penelitian ini pada umumnya sejalan dengan penelitian-penelitian lain yang menyatakan bahwa semakin tinggi stadium HIV maka semakin tinggi risiko TB. Seperti halnya penelitian di Bogor oleh Karima UQ et al., tahun 2017 dan penelitian lainnya juga menunjukkan hal yang serupa bahwa TB lebih cenderung terjadi pada pasien yang terdiagnosis HIV stadium 3 dan 4 daripada stadium 1 dan $2 .^{13,17}$ Begitu juga pada penelitian sebelumnya memperlihatkan bahwa stadium 3 dan 4 lebih banyak terdapat pada pasien dari pada stadium 1 dan 2 yaitu $94,4 \% .{ }^{18} \mathrm{Hal}$ ini disebabkan karena pada stadium 3 dan 4 terjadinya destruksi sel $\mathrm{CD} 4+$ yang sangat masif sehingga jumlah CD4+ kurang dari $200 \mathrm{sel} / \mathrm{mm}^{3}$. Maka integritas imun pada pasien HIV sangat rendah dan menyebabkan berkurangnya fungsi imun sehingga risiko terinfeksi bakteri TB menjadi lebih tinggi. ${ }^{18}$

Konsolidasi adalah salah satu karakteristik yang lebih umum dari infeksi paru, dan penampilannya bervariasi, tergantung pada organisme penyebab. ${ }^{19}$ Pada penelitian ini, kita dapat melihat karakteristik paling umum pasien TB dan HIV di RSUP Sanglah tahun 2017 - 2021 adalah konsolidasi dengan 20 kasus. Berdasarkan beberapa penelitian yang lainnya, semua variabel untuk karakteristik foto toraks bervariasi di beberapa penelitian tapi konsolidasi tetap menjadi karakteristik paling umum pasien TB dan HIV. Contohnya penelitian Hidayat EY et al., di RSUP Dr. Kariadi dan BKPM Semarang menyatakan konsolidasi merupakan variabel terbanyak $(58,3 \%)$ pada penelitian tersebut tapi diikuti dengan variabel limfadenopati $(4,2 \%)$ serta tidak ada variabel fibroinfiltrat. ${ }^{20}$ Kemudian, penelitian Sulaiman SC di RSUD Dr. Soetomo Surabaya juga menunjukkan bahwa konsolidasi adalah karakteristik paling banyak terdapat pada foto toraks yaitu $96 \% .{ }^{21}$ Begitu juga, penelitian Jendriella $J$ et al., pada tahun 2019 di Rumah Sakit Umum Arifin Achmad Provinsi Riau yang menyatakan bahwa konsolidasi adalah karakteristik paling umum dengan persentase $41,9 \%$ kemudian disertai penampilan foto toraks normal dengan presentase $21,8 \%{ }^{22}$

Berdasarkan data penelitian ini, dapat disimpulkan bahwa konsolidasi adalah karakteristik paling umum pada foto thoraks pasien HIV dan merupakan salah satu fitur utama pada TB aktif. Konsolidasi adalah proses pengisian alveolar oleh sel, eritrosit, air cairan edema (tergantung penyakitnya) untuk menggantikan udara pada ruang udara yang terkena, sehingga 
menimbulkan gambaran opaque pada foto thoraks. ${ }^{19}$ Meskipun konsolidasi merupakan karakteristik dominan pada penelitian ini dan juga penelitian banding yang digunakan, ditemukan karakteristik TB dan HIV lainnya di penelitian ini agak berbeda dengan penelitian banding lainnya. Hal ini karena tingkat keparahan penyakit TB dan HIV saat didiagnosis atau di rontgen dan dapat juga terjadi karena jumlah sampel yang digunakan berbeda berdasarkan tempat dan waktu pengambilan data.

\section{SIMPULAN}

Hasil penelitian ini menunjukkan bahwa sebagian besar karakteristik gambaran Tuberkulosis (TB) paru pada foto toraks pasien Human Immunodeficiency Virus (HIV) tahun 2017-2021 di RSUP Sanglah, Bali, Indonesia didominasi oleh usia 3039 tahun, jenis kelamin laki-laki, stadium 4, dan karakteristik konsolidasi pada foto toraks.

\section{KONFLIK KEPENTINGAN}

Penulis menyatakan bahwa tidak terdapat konflik kepentingan dalam penyusunan laporan penelitian ini.

\section{ETIKA PENELITIAN}

Penelitian ini telah mendapatkan persetujuan etik dari Komisi Etik, Fakultas Kedokteran, Universitas Udayana, Bali, Indonesia dengan nomor 190/UN14.2.2.VII.14/LT/2021 sebelum penelitian berjalan.

\section{PENDANAAN}

Penulis bertanggung jawab terhadap pendanaan penelitian ini tanpa melibatkan beasiswa, sponsor, ataupun sumber pendanaan lainnya.

\section{KONTRIBUSI PENULIS}

Seluruh penulis memiliki kontribusi yang sama dalam pembuatan laporan penelitian ini baik dari penyusunan kerangka konsep, pengumpulan data, analisis data, hingga interpretasi hasil penelitian dalam bentuk publikasi ilmiah.

\section{DAFTAR PUSTAKA}

1. MacNeil A, Glaziou P, Sismanidis C, Date A, Maloney S, Floyd K. Global Epidemiology of Tuberculosis and Progress Toward Meeting Global Targets - Worldwide, 2018. MMWR Morb Mortal Wkly Rep. 2020;69(11):281-285.

2. Fukunaga R, Glaziou P, Harris JB, Date A, Floyd K, Kasaeva T. Epidemiology of Tuberculosis and Progress Toward Meeting Global Targets Worldwide, 2019. MMWR Morb Mortal Wkly Rep. 2021;70(12):427-430.

3. Bruchfeld J, Correia-Neves M, Källenius G. Tuberculosis and HIV Coinfection. Cold Spring Harb Perspect Med. 2015;5(7):a017871.

4. Deeks SG, Overbaugh J, Phillips A, Buchbinder S. HIV infection. Nat Rev Dis Primers. 2015;1:15035.

5. Naif HM. Pathogenesis of HIV Infection. Infect Dis Rep. 2013;5(Suppl 1):e6.

6. Mulyadi, Fitrika Y. Hubungan tuberkulosis dengan HIV/AIDS. Idea Nursing Journal. 2011;2(2):162-166.

7. Zamy DA, Lestari BW, Hartantri Y. Gambaran Hasil Terapi TB Paru pada Pasien TB-HIV di RSUP dr. Hasan Sadikin Bandung Tahun 2012-2014. eJournal Kedokteran Indonesia. 2015;3(3):204-209.

8. Rao C, Kosen S, Bisara D, Usman Y, Adair $\mathrm{T}$, Djaja S, et al. Tuberculosis mortality differentials in Indonesia during 2007-2008: evidence for health policy and monitoring. Int J Tuberc Lung Dis. 2011;15(12):1608-14.

9. Philips JA, Ernst JD. Tuberculosis pathogenesis and immunity. Annu Rev Pathol. 2012;7:353384.

10. Sulis G, Roggi A, Matteelli A, Raviglione MC. Tuberculosis: epidemiology and control. Mediterr J Hematol Infect Dis. 2014;6(1):e2014070.

11. Rosa FS. Karakteristik Pasien Koinfeksi TBHIV di Rumah Sakit Umum Pusat Haji Adam Malik [Skripsi]. Repositori Institusi Universitas Sumatera Utara. 2018.

12. Soraya DAH, Artika DM. Profil Pasien Koinfeksi TB-HIV Di Rumah Sakit Umum Pusat Sanglah Bali Tahun 2013. E-Jurnal Medika Udayana. 2016;5(7):66-71.

13. Krisnahari KL, Sawitri AAS. Karakteristik Pasien HIV/AIDS dengan Koinfeksi Tuberkulosis di Rumah Sakit Umum Daerah (RSUD) Badung dan Klinik Bali Medika Kuta. E-Jurnal Medika Udayana. 2018;7(11):1-8.
14. Yusuf NF. Karakteristik Penderita Hiv/ Aids Dengan Ko-Infeksi Tuberkulosis Paru Di Rumah Sakit Umum Pusat Wahidin Sudirohusodo Makassar Periode Januari Sampai Juni 2016 [Skripsi]. Universitas Hasanuddin. Makassar. 2017.

15. Tiffany C. Studi Penggunaan Antituberkulosis Pada Pasien AIDS Rawat Inap Dengan Tuberkulosis Paru (Penelitian dilaksanakan di RSUD Dr. Saiful Anwar Malang) [Skripsi]. Fakultas Farmasi Universitas Airlangga. 2016

16. Rosamarlina NFN, Murtiani F, Setianingsih TY, Permatasari D. Profil Pasien Suspek Koinfeksi TB pada HIV di Rumah Sakit Penyakit Infeksi (RSPI) Prof. Dr. Sulianti Saroso Tahun 2015. The Indonesian Journal of Infectious Diseases. 2017;3(1):14-21.

17. Karima UQ, Sudaryo MK, Kiptiyah NM. Prediktor Kejadian TB pada ODHA di Salah Satu RS Pemerintah Bogor, Tahun 20142016. Jurnal Epidemiologi Kesehatan Indonesia. 2017;1(2):25-34.

18. Praptiwi DRNL, Karjadi TH, Nelwan EJ, Rumende CM. Faktor-Faktor yang Berhubungan dengan Tertundanya Inisiasi Terapi Antiretroviral pada Pasien dengan Infeksi Human Immunodeficiency Virus. Jurnal Penyakit Dalam Indonesia. 2016;3(3):151-157.

19. Walker CM, Abbott GF, Greene RE, Shepard JA, Vummidi D, Digumarthy SR. Imaging pulmonary infection: classic signs and patterns. AJR Am J Roentgenol. 2014;202(3):479-492.

20. Hidayat EY, Zulqarnain N, Sofro MAU. Perbandingan Gambaran Foto Toraks Pasien TB-HIV Dua dan Enam Bulan Pengobatan Anti-Tuberkulosis+ Anti-Retroviral. Jurnal Radiologi Indonesia. 2015;1(2):91-98.

21. Sulaiman SC. Profil TB Paru MDR (MULTIDRUG RESISTANT) pada Radiografi Toraks (Studi Retrospektif di RSUD DR. Soetomo Surabaya September 2015-Maret 2018) [Tesis]. Program Studi Radiologi Universitas Airlangga. 2019.

22. Jendriella J, Yazmiati D, Makmur A, Saad A. Gambaran Radiografi Toraks Pasien HIV Dengan Tuberkulosis Paru Berdasarkan Nilai CD4 Di Rumah Sakit Umum Arifin Achmad Provinsi Riau. Jurnal Ilmu Kedokteran. 2019;13(1):36-43.

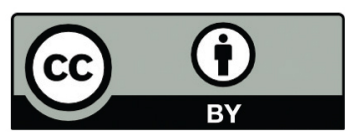

This work is licensed under a Creative Commons Attribution 